\title{
NOTA DOS EDITORES
}

Temos a honra de trazer à publicação o presente número da Suffragium - Revista do Tribunal Regional Eleitoral do Ceará no seu novo formato. A Suffragium vem sendo publicada há mais de sessenta anos, tendo passado por diversas transformações, convertendo-se num importante veículo para exposição de artigos e doutrinas de autores regionais e nacionais, bem como para a divulgação da jurisprudência do Tribunal Superior Eleitoral e do Tribunal Regional Eleitoral do Ceará.

Agora em nova fase, foram adotados procedimentos com vistas a propiciar à Suffragium o cumprimento de requisitos necessários à sua equiparação a publicações científicas de elevado nível, um dos quais consistiu em se organizar editorialmente de acordo com os parâmetros exigidos para periódicos nacionais e estrangeiros. Foi a partir desta diretriz que o TRE-CE, por sua Escola Judiciária Eleitoral, decidiu reorganizar a Revista.

Abrangendo as áreas do Direito Constitucional, do Direito Eleitoral e da Ciência Política, e em sintonia com as discussões teóricas e concretas sobre esses temas, a Revista não poderia deixar de se incorporar à atualidade e ao pluralismo de posições que estão presentes nos assuntos a que se dedica, trazendo para seus leitores publicações de autores nacionais e estrangeiros, o que muito prestigia a publicação. Os que se sentirem motivados a escrever para a Suffragium, ficam convidados para o envio de suas contribuições.

Por fim, após o hiato em 2018, e agora somente no formato eletrônico, a Revista segue com o número 17 , volume 10 , de 2019 , reafirmando, assim, o compromisso com sua regular periodicidade e percurso editorial.

\author{
Juiz Roberto Viana Diniz de Freitas \\ Editor-Chefe
}

Profa. Dra. Raquel Cavalcanti Ramos Machado

Editora-Adjunta

Prof. Dr. Martonio Mont'Alverne Barreto Lima

Editor-Adjunto 